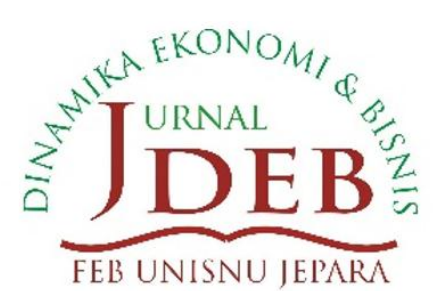

Jurnal Dinamika Ekonomi dan Bisnis, 17 (01) 2020, 1-7

https://ejournal.unisnu.ac.id/JDEB

Terakreditasi Sesuai Kutipan Keputusan Direktur Jenderal Penguatan Riset dan Pengembangan, Kementerian Riset, Teknologi, dan Pendidikan Tinggi Republik Indonesia Nomor: 21/E/KPT/2018

\title{
ANALISIS PERSEPSI MAHASISWA TERHADAP METODE PENGAJARAN KREASI BISNIS
}

\author{
Muliadi Palesangi ${ }^{1)}$, Sri Widya Wijanarti' ${ }^{2}$, Sonny Agustiawan ${ }^{3)}$
}

Sekolah Bisnis dan Ekonomi, Universitas Prasetiya Mulya ${ }^{123)}$

Email: muliadi.palesangi@pmbs.ac.id ${ }^{1)}$ sriwidya.wijanarti@pmbs.ac.id ${ }^{2)}$, sonny.agustiawan@pmbs.ac.id

\begin{abstract}
In the world of entrepreneurship education, it is important for educators to find the combination of entrepreneurial teaching methods that relevant to the learning goals and students' needs. This quantitative research aims to get an overview from students' perceptions of Business Creation's teaching methods in Prasetiya Mulya University, S1 Business Program. The results of the study revealed that discussion about STDP, Marketing Mix and BMC perceived as three important topics in starting a business in the aspect of conceptual lecture. The first and final phases of the competition are perceived to have a positive impact to fostering an entrepreneurial spirit in aspects of competition simulation. Whereas in the aspect of group dynamics, the factors that greatly influence group performance are communication and collaboration. The most interesting discussion topics for students are Opportunity, BMC, and Operation Skill.
\end{abstract}

Keywords: Business creation, entrepreneurship education, learning methods

\section{Abstrak}

Kombinasi metode pengajaran yang relevan dengan sasaran pembelajaran dan kebutuhan peseta didik sangat dibutuhkan dalam dunia pendidikan kewirausahaan. Penelitian kuantitatif ini bertujuan untuk mendapatkan persepsi Mahasiswa terhadap metode pengajaran mata kuliah Kreasi Bisnis di Program S1 Bisnis Universitas Prasetiya Mulya. Pada aspek perkuliahan konseptual, pembahasan tentang STDP, Marketing Mix dan BMC dipersepsikan sebagai tiga topik penting dalam memulai bisnis. Kompetisi tahap awal dan final, dipersepsikan dapat memberikan dampak positif dalam menumbuhkan jiwa kewirausahaan pada aspek simulasi kompetisi. Sedangkan pada aspek dinamika kelompok, faktor yang sangat mempengaruhi kinerja kelompok adalah komunikasi dan kerjasama. Topik bahasan yang paling menarik bagi mahasiswa adalah Opportunity, BMC, dan Operation Skill.

Kata Kunci: Kreasi Bisnis, Pendidikan Kewirausahaan, Metode Pengajaran

Sitasi: Palesangi, M., Wijanarti, S.W., dan Agustiawan, S. (2020). Analisis Persepsi Mahasiswa Terhadap Metode Pengajaran Kreasi Bisnis, Jurnal Dinamika Ekonomi dan Bisnis, 17 (01) 2020, 1-7. 


\section{PENDAHULUAN}

Kemampuan meramu metode pengajaran yang sesuai dengan kebutuhan pembelajaran menjadi faktor kunci keberhasilan pendidikan kewirausahaan (Lee et.al, 2006). Metode pengajaran kewirausahaan dapat dikelompokkan menjadi dua: metode tradisional dan metode inovatif. Metode tradisional hanya mengandalkan perkuliahan tatap muka, buku teks dan minim interaksi, sedangkan metode inovatif mengombinasikan beragam aktivitas seperti perkuliahan tatap muka, permainan, simulasi kompetisi dan dinamika kelompok (Bennet, 2006; dan Mwsalwilba, 2010).

Pendidik kewirausahaan mengombinasikan beragam metode pengajaran dalam rangka memenuhi keragaman gaya belajar siswa. Oleh karena itu, Pendidik kewirausahaan perlu memiliki kemampuan mendesain metode pengajaran yang sesuai dengan sasaran pembelajaran dan kebutuhan peserta didik (Lee et.al, 2006; Soehadi, et.al, 2011).

Program S1 Bisnis Universitas Prasetiya Mulya menerapkan metode pengajaran inovatif untuk menghasilkan wirausaha terdidik dengan mengadaptasi metode pembelajaran berbasis pengalaman. Penelitian ini memfokuskan kajian pada mata kuliah Kreasi Bisnis, salah satu mata kuliah yang berbasis pengalaman di program S1 Bisnis Universitas Prasetiya Mulya. Kreasi Bisnis terus dievaluasi pelaksanaannya pada setiap akhir semester. Namun evaluasi perkuliahan selama ini masih berdasarkan masukan tim pengajar Kreasi Bisnis. Sementara umpan balik dari Mahasiswa terhadap metode pengajaran mata kuliah ini belum pernah dilakukan melalui kajian terstruktur. Oleh karena itu, penelitian ini penting dilakukan untuk mengetahui persepsi Mahasiswa terhadap metode pengajaran Kreasi Bisnis.

Hasil penelitian ini akan menjadi pertimbangan dalam mengevaluasi metode pengajaran Kreasi Bisnis di Universitas Prasetiya Mulya. Penelitian ini bertujuan untuk mengidentifikasi persepsi Mahasiswa terhadap metode pengajaran Kreasi Bisnis yang ditinjau dari 5 (lima) aspek: (1) perkuliahan konseptual; (2) simulasi kompetisi; (3) fasilitator pembelajaran; (4) dinamika kelompok, dan (5) prioritas topik.

\section{METODE PENGAJARAN KREASI BISNIS}

Pendidikan kewirausahaan adalah upaya pengembangan sikap, perilaku dan kapasitas kewirausahaan yang bertujuan menyiapkan peserta didik untuk mengeksplorasi peluang, mengasah kreativitas dan merintis bisnis. Ruang lingkup pendidikan kewirausahaan meliputi peserta didik, tujuan, konten dan metode pengajaran yang beragam (Fayolle dan Gailly, 2008).

Studi menarik dari Mwasalwiba (2010) yang mengkaji peringkat metode pengajaran kewirausahaan berdasarkan intensitas penggunaannya. Pengukurannya menggunakan rentang peringkat 1 sampai dengan 13. Peringkat 1 berarti paling sering digunakan dan peringkat 13 artinya paling jarang digunakan. Peringkatnya sebagai berikut: (1) Perkuliahan konseptual; (2) Studi kasus; (3) Diskusi kelompok; (4) Simulasi bisnis; (5) Video dan film; (6) Role models dan dosen tamu; (7) Rencana bisnis; (8) Kerja proyek; (9) Permainan dan kompetisi; (10) Kreasi bisnis rintisan; (11) Lokakarya; (12) Presentasi; (13) Kunjungan lapangan.

Peringkat nomor 1 sampai dengan peringkat 3 adalah metode pasif yang umum digunakan di sekolah bisnis. Metode ini kurang efektif dalam membangkitkan jiwa kewirausahaan. Sebaliknya, peringkat nomor 9 sampai dengan peringkat 13 adalah metode 
aktif yang efektif untuk membangkitkan jiwa kewirausahaan.

Pengembangan pengajaran kewirausahaan berbasis metode inovatif terus menjadi perhatian Pendidik Kewirausahaan. Neck et.al (2014) mempromosikan metode pengajaran yang dikenal dengan istilah "Five Spesific Practice of Entrepreneurship", sebuah bentuk pengajaran kewirausahaan berbasis metode yang terdiri dari portofolio praktik: praktik bermain, praktik empati, praktik kreasi, praktik eksperimentasi, dan praktik refleksi. Kelima portofolio praktik mendorong penciptaan bisnis-bisnis baru. Metode ini mendorong siswa dari sekadar membicarakan, dan mengetahui menjadi menggunakan dan mewujudkan.

Mata Kuliah Kreasi Bisnis adalah mata kuliah jangkar pada semester 3. Mata kuliah ini merupakan mata kuliah berbasis project dengan bobot perkuliahan sebesar 4 (empat) Satuan Kredit. Tanggung jawab pembelajaran pada mata kuliah jangkar ada di mahasiswa, oleh karena itu mata kuliah ini menggunakan pendekatan metode pengajaran berbasis pengalaman dalam aspek perkuliahan konseptual, simulasi kompetisi, fasilitator pembelajaran, dan dinamika kelompok. Perkuliahan konseptual adalah sesi tatap muka di kelas dengan topik bahasan: eksplorasi peluang, model bisnis, dan manajemen fungsional untuk bisnis rintisan. Sesi perkuliahan konseptual diselenggarakan sebanyak delapan sesi atau 50\% dari total sesi perkuliahan.

Simulasi Kompetisi adalah sesi pembelajaran dalam bentuk kompetisi bisnis antar kelompok. Alokasi waktu simulasi kompetisi sebanyak 7 (tujuh) sesi atau 44\% dari total alokasi sesi perkuliahan. Selama masa perkuliahan Kreasi Bisnis kelompok Mahasiswa melalui tujuh tahapan kompetisi (mulai dari fase 1A sampai Fase 3B). Alokasi sesi perkuliahan dan simulasi kompetisi dapat dilihat pada tabel 1.

\section{Tabel 1. Alokasi Sesi Perkuliahan dan Simulasi Kompetisi}

\begin{tabular}{cll}
\hline Sesi & Topik & Kompetisi \\
\hline 1 & Peluang Bisnis & \\
2 & Model Bisnis & \\
3 & Model Bisnis (Review) & \\
4 & Manajemen dan Kepemimpinan & Fase 1A \\
5 & Presentasi Kualifikasi & Fase 1B (Eliminasi) \\
6 & Pemasaran untuk Usaha Rintisan & Fase Play Off (Eliminasi) \\
7 & Presentasi - Juri Fasilitator Kategori & \\
8 & Presentasi - Juri Fasilitator Kategori & Fase 2A \\
9 & Operasi Usaha Rintisan & \\
10 & Presentasi Kualifikasi & Fase 2B (Eliminasi) \\
11 & Keuangan Usaha Rintisan & \\
12 & Presentasi - Juri dosen dan juri praktisi & Fase 3A (Eliminasi) \\
13 & Rencana Bisnis & \\
14 & Presentasi - Juri dosen dan juri praktisi & \\
15 & Ujian Akhir Semester (UAS) & \\
16 & Presentasi Final di Entrepreneur Day - Juri eksternal & Fase 3B \\
\hline
\end{tabular}

Sumber: RKPS Mata Kuliah Kreasi Bisnis diolah, 2019

Fasilitator Pembelajaran adalah pengajar mata kuliah kreasi bisnis. Setiap kelas terdiri 
dari dua orang, yakni 1 orang dosen full time (akademisi) dan 1 orang dosen part time (pengusaha). Fasilitator bertanggung jawab melaksanakan sesi perkuliahan dan sesi kompetisi. Pada sesi perkuliahan, fasilitator akan membawakan materi konseptual sedangkan pada sesi kompetisi, fasilitator berperan sebagai coach yang akan memberi tanggapan dan arahan terhadap project kelompok.

Dinamika Kelompok Setiap Mahasiswa tergabung dalam satu kelompok yang beranggotakan 5 orang. Pembentukan kelompok bertujuan melatih Mahasiswa bekerja sama sekaligus mensimulasikan dinamika kelompok yang dialami oleh seorang pebisnis.

\section{METODOLOGI}

Penelitian ini adalah penelitian kuantitatif dengan pendekatan survei. Kuesioner terdiri dari 8 bagian dan 38 pertanyaan dengan rincian pada tabel 2. Responden penelitian sebanyak 530 orang adalah Mahasiswa angkatan 2016 Program studi S1 Manajemen bisnis Universitas Prasetiya Mulya yang merupakan peserta mata kuliah Kreasi Bisnis tahun ajaran 2017/2018. Penelitian ini menggunakan kuesioner sebagai instrumen pengumpulan data, terdiri dari 8 bagian dan 38 pertanyaan.

Tabel 2. Topik Pertanyaan Kuesioner

\begin{tabular}{llll}
\hline Bagian & \multicolumn{1}{c}{ Topik Pertanyaan } & $\begin{array}{c}\text { Jumlah } \\
\text { Pertanyaan }\end{array}$ & Skala Pengukuran \\
\hline 1 & Perkuliahan Konseptual & 18 & Likert \\
2 & Simulasi Kompetisi & 7 & Likert \\
3 & Saran Fasilitator & 4 & Likert \\
4 & Dinamika Kelompok & 3 & Likert \\
5 & Prioritas Topik & 1 & Pemeringkatan \\
6 & Saran Topik & 1 & Isian \\
7 & Saran Kreasi Bisnis & 1 & Isian \\
8 & Identitas Responden & 3 & Ordinal \\
\hline
\end{tabular}

Sumber: instrumen penelitian diolah, 2019

Responden menanggapi pertanyaan tentang aspek perkuliahan konseptual, simulasi kompetisi, fasilitator pembelajaran, dan dinamika kelompok dalam kuesioner yang menggunakan skala likert dari 1 = sangat tidak setuju (STS) sampai 5 =sangat setuju (SS). Lalu data diolah menggunakan perhitungan SPSS - Descriptive Analysis dengan menggunakan pengukuran Mean menjadi basis penilaian tanggapan responden. Sedangkan untuk aspek prioritas topik, responden diminta membuat peringkat topik utama perkuliahan konseptual dengan rentang 1 (paling penting) sampai 7 (paling tidak penting).

Analisis data penelitian ini menggunakan statistik deskriptif. Peneliti hanya mendeskripsikan variabel secara sistematik dan lebih menekankan pada data faktual daripada penyimpulan, tanpa membuat perbandingan variabel tersebut pada sampel lain, dan peneliti tidak mencari hubungan variabel tersebut dengan variabel lain. 


\section{HASIL DAN PEMBAHASAN}

\section{Deskripsi Data Tentang Metode Pengajaran dalam Aspek Perkuliahan Konseptual}

Pada bagian ini peneliti meminta pendapat responden terkait topik bahasan konseptual yang diajarkan di Kreasi Bisnis. Tiga topik utama yang dianggap penting oleh responden dalam memulai bisnis adalah STPD - Segmentation, Targeting, Positioning dan Differeniation (mean 4.48), Marketing Mix (mean = 4.39) dan BMC-Business Model Canvas ( mean $=4.38)$.

STPD dan Marketing Mix adalah topik bahasan pada materi "marketing for startups" pada perkuliahan sesi ke-6. Bahasan STPD tentang proses perancangan STPD yang merupakan konsep dasar bagi Mahasiswa dalam memahami konsumen. Sedangkan pada bagian marketing mix, membahas empat komponen marketing mix yakni produk, harga, promosi, dan distribusi.

Pemahaman tentang konsumen pada STPD sangat berguna bagi Mahasiswa ketika merancang marketing mix. Selanjutnya, responden menganggap BMC merupakan topik yang bermanfaaat dalam memulai bisnis, karena BMC merupakan tools utama yang digunakan dalam mata kuliah Kreasi Bisnis. Bahasan tentang BMC yang diselenggarakan pada perkuliahan sesi ke-2 \& 3 dalam bentuk workshop, sesi perkuliahan yang memadukan penjelasan konsep dan latihan aplikasi konsep BMC.

\section{Deskripsi Data Tentang Metode Pengajaran dalam Aspek Simulasi Kompetisi}

Responden mempersepsikan bahwa kompetisi awal Kreasi Bisnis menumbuhkan semangat dalam proses pencarian ide bisnis (mean $=4.21$ ). Sedangkan kompetisi final Entrepreneur Day (ED) atau fase $2 \mathrm{~b}$ memberikan dampak positif terhadap penyempurnaan ide bisnis (mean $=4.19)$. Hal ini karena kompetisi final ED adalah kompetisi pamungkas yang mempertandingkan para pemenang dari fase sebelumnya. Tim yang lolos wajib mengakuisisi 1 tim yang tidak lolos, di kategori yang sama. Tim yang lolos pada fase pamungkas ini mendapatkan kesempatan berjualan di pameran ED. Perolehan poin dan kesempatan tampil di ED menjadi daya tarik bagi kontestan. Temuan menariknya adalah mekanisme kompetisi memberikan dampak positif dalam menumbuhkan jiwa wirausaha (mean $=4.09$ ).

Namun yang perlu menjadi perhatian adalah adanya dua aspek yang memiliki mean terendah yakni mekanisme eliminasi (mean $=3.84$ ) dan mekanisme merger $($ mean $=3.90)$. Intervensi eliminasi dan merger menjadi tantangan tersendiri bagi tim, karena tim harus beradaptasi lagi dengan anggota tim yang baru bergabung. Pada fase ini, seringkali ditemukan adanya Mahasiswa yang "patah semangat" karena kalah dan harus bergabung ke tim baru. Untuk itu, penanggung jawab Kreasi Bisnis perlu meninjau kembali relevansi kedua intervensi ini.

\section{Deskripsi Data Tentang Metode Pengajaran dalam Aspek Fasilitator Pembelajaran}

Temuan menarik dari aspek fasilitator pembelajaran adalah bahwa saran fasilitator kategori lebih signifikan berdampak pada konsep ide produk dan konsep ide bisnis dibandingkan dengan saran dari juri eksternal. Hal ini karena fasilitator kategori memberikan saran pada tahap-tahap awal perintisan bisnis sehingga besar kemungkinannya akan terpakai 
oleh kelompok, khususnya berdampak positif pada konsep produk (mean $=4,10$ ) dan berdampak signifikan pada konsep ide bisnis (mean $=4,04$ ).

Rendahnya dampak saran juri eksternal atau juri praktisi terhadap perubahan konsep bisnis dan perbaikan konsep produk bisa dipahami karena pada fase 2B (juri eksternal mulai terlibat). Fase dimana setiap tim telah memiliki konsep produk dan bisnis yang lebih matang. Sehingga pada fase ini, kecil sekali kemungkinannya kelompok melakukan iterasi lagi pada konsep produk dan bisnisnya.

\section{Deskripsi Data Tentang Metode Pengajaran dalam Aspek Dinamika Kelompok}

Simulasi Kreasi Bisnis memang dirancang untuk meningkatkan soft skills komunikasi dan kerjasama sebagai upaya pemupukan jiwa kewirausahaan peserta didik. Hal ini terkonfirmasi pada temuan yang terkait dengan aspek dinamika kelompok. Responden mempersepsikan bahwa komunikasi dalam kelompok (mean =4,57) sangat mempengaruhi kinerja kelompok. Sementara dari sisi kerjasama dalam kelompok berdampak positif terhadap motivasi dalam memulai bisnis $($ mean $=4.30)$.

Aspek dinamika kelompok juga menghadirkan temuan menarik, bahwa jiwa kewirausahaan responden tumbuh karena bekerja sama dalam kelompok (Mean = 4,23).

\section{Deskripsi Data Tentang Metode Pengajaran dalam Aspek Prioritas Topik}

Ada 3 (tiga) topik yang menempati urutan prioritas tertinggi yakni (1) opportunity; (2) BMC; dan (3) operation skill. Temuan menarik untuk topik opportunity, jika dibandingkan dengan bahasan pada bagian aspek perkuliahan konseptual, topik opportunity termasuk tiga topik yang memiliki mean terendah. Tapi, pada bagian pemeringkatan ini responden memberikan peringkat prioritas nomor 1 untuk topik opportunity.

Hal ini merupakan indikasi perlunya mengkaji ulang konten topik opportunity ini. Dari sisi konten, porsi bahasan opportunity hanya menjadi salah satu pokok bahasan pada materi pertemuan pertama yakni overview mata kuliah (40\%), review entrepreneur day (40\%), dan the opportunity (20\%). Dari sisi komposisi terlihat bahwa bahasan topik opportunity memiliki porsi pembahasan terkecil. Hal ini perlu menjadi bahan evaluasi untuk mempertimbangkan pengayaan konten untuk the opportunity.

Selain itu, bagian yang perlu dicermati lebih lanjut adalah rendahnya prioritas pada bahasan manajemen fungsional yakni professional management \& leadership (4), marketing for startup (5) dan finance for startup (6). Hal ini memberikan sinyal perlunya mengkaji ulang tentang relevansi konten untuk ketiga aspek fungsional tersebut.

\section{SIMPULAN DAN SARAN}

Studi deskriptif mengenai persepsi mahasiswa terhadap metode pengajaran Kreasi Bisnis mengungkap temuan menarik. Dari aspek perkuliahan konseptual, bahasan STPD, marketing mix dan BMC dipersepsikan sebagai tiga topik bahasan utama yang penting dalam memulai bisnis. Sementara dari aspek simulasi kompetisi, responden mempersepsikan bahwa kompetisi awal dan final memberikan dampak positif dalam menumbuhkan jiwa wirausaha. Namun perlu meninjau ulang mengenai intervensi eliminasi dan merger. 
Saran fasilitator kategori lebih signifikan berdampak pada konsep ide produk dan bisnis dibandingkan dengan saran dari juri eksternal. Simulasi Kreasi Bisnis dirancang untuk meningkatkan soft skills komunikasi dan kerjasama sebagai upaya pemupukan jiwa kewirasuahaan peserta didik. Hal ini terkonfirmasi pada temuan aspek dinamika kelompok. Responden mempersepsikan bahwa komunikasi dan kerjasama sangat mempengaruhi kinerja kelompok.

Tiga topik bahasan yang menjadi prioritas adalah topik opportunity, BMC, dan operation skill. Porsi bahasan opportunity perlu ditambah, mengingat saat ini bahasan opportunity hanya menjadi salah satu sub bahasan pada materi pertemuan pertama. Namun, perlu menjadi perhatian ke depan adalah konten aspek fungsional yakni pemasaran, keuangan dan SDM agar lebih berorientasi relevan dengan bisnis rintisan.

Arah penelitian berikutnya diharapkan dapat lebih berorientasi kepada eksplorasi pengajaran kewirausahaan berbasis metode. Lebih baik lagi, jika pendekatan penelitian melalui riset kausal sehingga dapat memberikan sumbangan gagasan untuk pengayaan konten mata kuliah Kreasi Bisnis ke depan.

\section{DAFTAR PUSTAKA}

Bennett, R. (2006). Business lecturers' perceptions of the nature of entrepreneurship. International Journal of Entrepreneurial Behavior \& Research, 12(3), 165-188.

Fayolle, A. and Gailly, B. (2008). From craft to science: Teaching models and learning processes in entrepreneurship education. Journal of European Industrial Training, 32 (7), 569-593.

Lee, S., Lim, S. and Pathank, R. (2006). Influences on students attitudes toward entrepreneurship: A multi-country study. International Entrepreneurship Management Journal, 2(3), 351-366.

Mwasalwiba, E.S. (2010). Entrepreneurship education: A review of its objectives, teaching methods, and impact indicators. Education - Training, 52(1), 20-47.

Neck, Heidi M., Patricia G. Greene, and Candida G. Brush. (2014). Teaching entrepreneurship: A practice-based approach. Edward Elgar Publishing.

Soehadi, A.W., Suhartanto, E., Winarto, V., Kusmulyono, M.S. (2011). Prasetiya Mulya EDC on Entrepreneurship Education. Jakarta: Prasetiya Mulya Publishing. 